\title{
The Trauma of Representation
}

\author{
Visual Culture, Photojournalism \\ and the September 11 Terrorist Attack
}

\author{
Kari Andén-Papadopoulus
}

What is the cultural significance of the fact that news photographs of 9-11 are being appropriated and recirculated in different cultural contexts: in official museums and popular make-shift galleries, in memorial books and semi-private sites on the web, and in the form of souvenirs sold by street vendors near the World Trade Center site? What happens to the meaning and function of journalistic images when they are transplanted into high cultural, or moreover, into downright popular-commercial discourses? How are we to account for this widespread cultural circulation of photographic images in the wake of 9-11, of the wish to create them, look at them, buy, collect and keep them? Are they, as Jean Baudrillard would have it, 'sites of disappearance of meaning and representation', detached signifiers that overtake and do away with referential reality? Or, on the contrary, are they sites that process and help us re-connect with the real, tangible objects that serve as visual verification that these incomprehensible events actually took place? And are we to believe the oft-repeated statement that 9-11 implies a comeback for the pre-television medium of still photography, which has succeeded where television seemingly failed in enabling memory, mourning, and working through of these traumatic events?

This article discusses these questions by examining and comparing the recirculation of journalistic images in two different contexts: the grass-roots photo show here is new york: a democracy of photographs, which sells images from 9-11 and its aftermath taken by both press photographers and amateurs alike, and the phenomenon of street ven-

JMK, Stockholm University, P.O. Box 27861, SE11593 Stockholm, anden@jmk.su.se dors selling knockoff press photographs by the World Trade Center site. The overall aim is to demonstrate the necessity of a visual culture perspective to photojournalism: an approach that takes account of the fact that many news images tend to cross not only cultural and national boundaries, but media and genre boundaries as well. Clearly it takes a perspective like visual culture to examine what happens to the meaning and function of news photographs when they start circulating in the wider culture, as well as how we as individuals and groups use them to make sense of traumatic historical events like the September 11 attacks.

\section{Unreality TV}

From a media perspective, the events of September 11 first and foremost stand out as a landmark in the history of television news. All over the world, people were glued to the television news from America, repeatedly watching the same loops of video footage, as the plane exploded into the second tower of the World Trade Center and the Lower Manhattan skyline disappeared under a grey cloud of dust and debris. The incredible live images were replayed throughout the day, as news journalists and viewers alike struggled to make sense of the catastrophic scenes.

In psychoanalytic theory, repetition plays an essential role in the different processes of both 'acting out' and 'working through' (Freud, 1914; Freud, 1917). The latter process entails the self-conscious repetition of a traumatic event - in actions, dreams, words, images - coupled with sustained efforts towards interpretation, in order to integrate the trauma into a psychic structure, a symbolic order. Acting out, on the other hand, is repetition as com- 


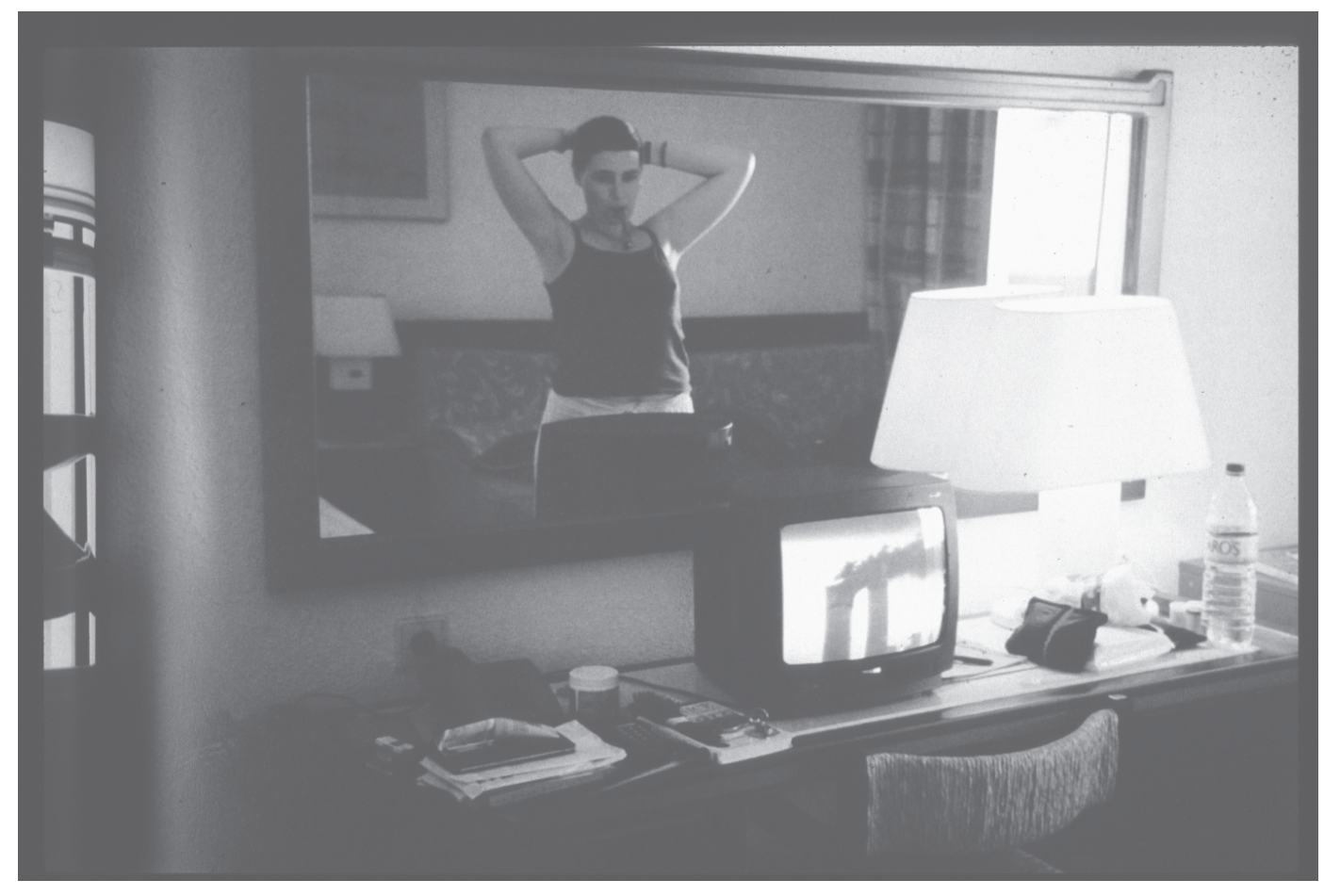

Photograph taken by amateur September 11, from here is new york.

pulsion, an obsessive fixation on the traumatic event, a manic re-enactment of it without any hermeneutic attempts. This notion of shocked subjectivity and compulsive repetition applies to September 11: the television networks seem to have functioned much as a traumatized psyche, invaded by and helplessly repeating the gruesome images without being able to integrate them into an interpretative framework. Furthermore, following Hal Foster's line of thought, the replaying TV-images may have involved not only a reproducing of traumatic effect, but also a producing of it. As a CBS executive states, by the end of the day news editors began to realize that 'the moving images were hurting people. It wasn't good for the viewers, and not for us journalists either'. ${ }^{1}$ Instead, the television networks started using still images of the defining moments of the attacks, since they were considered less upsetting.

This journalistic bewilderment was, of course, a symptom of a wider cultural shock. The overall reaction to the terrorist events, in New York City, in America and the rest of the world, seems to have been disbelief. Watching the scenes of chaos and destruction, whether on the spot in Lower Manhattan or on TV, was to witness 'the inexpressible, the in- comprehensible, the unthinkable' as the front page of The New York Times stated the day after.

Faced with the September 11 attacks, people seem fundamentally to have responded in the same way regardless of whether they were direct eye-witnesses to the events or second-hand viewers of it on the television screen: this was unreal, beyond words, an out-of-body experience, pure fiction - like a Hollywood disaster movie. Unable to make sense of the brutal drama as reality, to account for it as a category of the real, people in and outside of the media constantly referred to it in terms of popular movie fiction. How are we to understand these ubiquitous Hollywood comparisons? As a psychic defense against an overdose of reality whereby the statement 'it was like a movie' easily slips into 'it was a movie'? As a fundamental, culturally determined inability to deal with reality other than in the good-versus-evil format of Hollywood melodrama? As a sign of the ultimate triumph of the image and imaginary over referential reality, the final collapse of the two categories - reality as fiction, fiction as reality? Are we to believe Baudrillard when he makes the case in customarily provocative terms that the images took the events of 9-11 'hostage' and derealised them (Baudrillard, 2002)? 


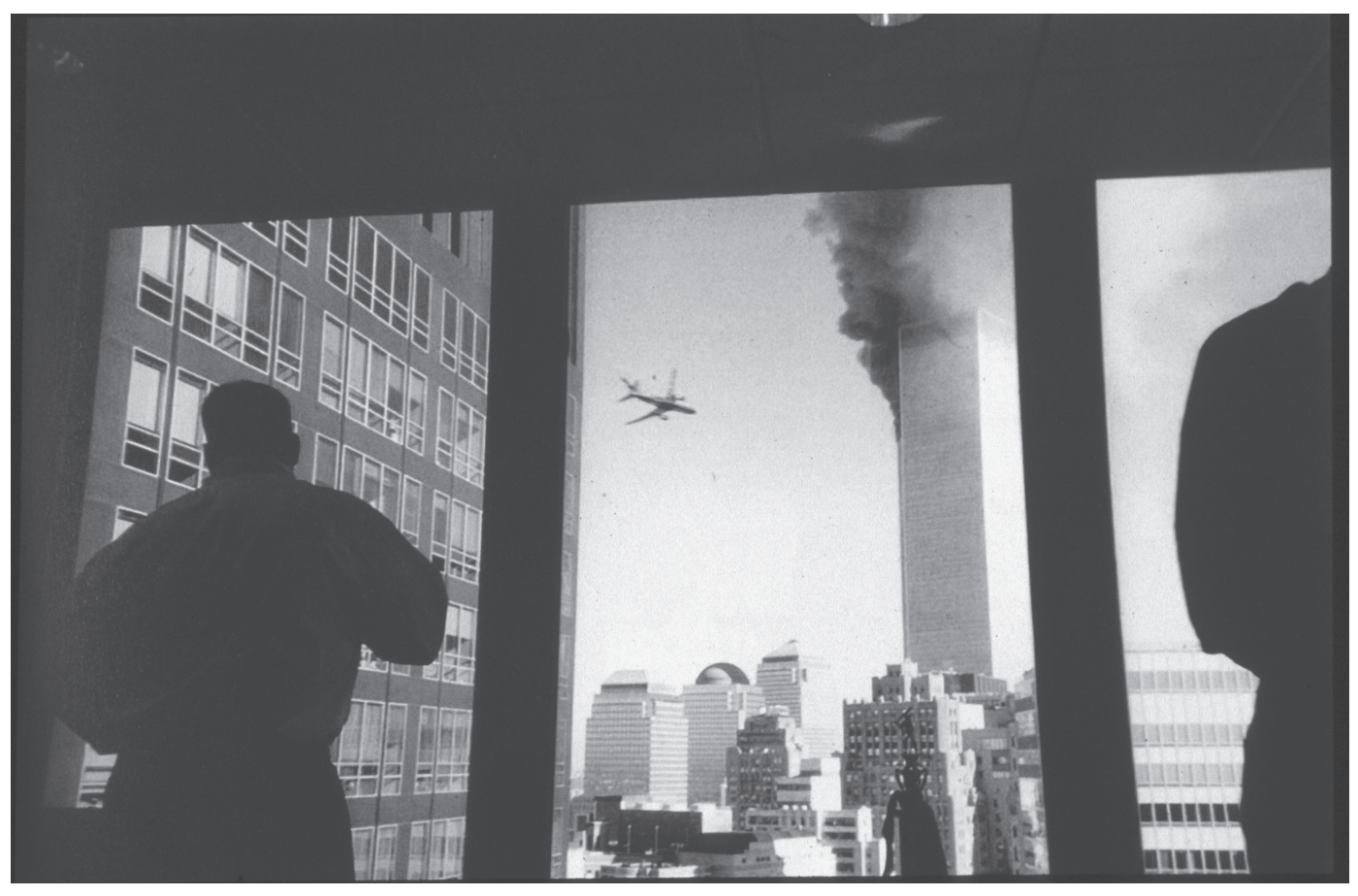

Photograph taken by amateur September 11, from here is new york.

Arguably, these Hollywood references must be understood figuratively, as indicating the (initial) difficulty of adequately making sense of the disaster. It is a cliché, simply expressing the sense of unreality in the face of these traumatic events. This reaction is comparable to the limits of sensibility which, as the prominent Holocaust scholar Geoffrey Hartman points out, frequently surfaces in survivor narratives: 'So threatening was the shoah that disbelief $[\ldots]$ touched the survivors themselves and added to the silence of the world. When speech returns, two phrases stand out in their testimony: 'I was there' and 'I could not believe what my eyes had seen' (Hartman, 1992: 326). In the case of 9-11, the question that looms large is what role the mediations of television played in this conflict between what was seen and what is believable. Did television serve to connect or disconnect people with the real, to verify or derealise the traumatic events? This question invokes a tangled subject, related to media event theory (Dayan and Katz, 1992), which over the last decade has received increasing attention in televison studies: what are the similarities and differences between 'first-hand' and 'second-hand' witnessing? How does the experience of being physically present at an event compare to the experience of being an absent television viewer? Can television close the fac- tual gap between here and there, now and then (if not a live broadcasting) and elicit from viewers highly engaged and empathetic viewing positions, helping processes of bearing witness, healing and working through (Ellis, 2000)?

TV-scholar John Corner makes the case that television as a medium has a unique power to engage the viewer's personal and social identity as 'witness', due to its visual capacity to let people 'see for themselves' (Corner, 1996: 30). However, as Corner himself stresses, more inquiry is needed into the precise ways in which audiences view television. One should therefore be careful with generalizing statements about 'the television experience' or the power of 'the television medium'. In contrast to John Corner's thesis that the power of television to call viewers into empathy and understanding inheres in its 'visual immediacy' (Corner, 1996:30), the case of 9-11 implies rather that this power inheres in its genre specific mediation - narrative framing, symbolic representation - of historical events. Obviously, during the day of the terrorist attacks television initially failed exactly to provide a narrative frame for the live broadcast images of the World Trade Center disaster. Insights from the field of trauma studies point to the danger of forcing 'immediate' visualisations of violence on the spectator: what is presented 'becomes an offense, an aggres- 
sion, and may arouse such strong defenses that - in a profound way - we do not believe that what we are made to feel and see is part of reality' (Hartman, 1992: 326). Thus, an imaging that allows reflection and interpretation, that invents allusions' to the traumatic real rather than somehow attempts to present it as such, may be more likely to move rather than overwhelm and incite disbelief in the viewer.

If people couldn't make sense of television's live broadcasting and compulsive instant replay of disaster images the first day, it may be because of the initial lack of a coherent narrative framework. What we saw was the news organizations own confusion and struggle to create a story, to invent a framework to help them and their audiences make sense of the seemingly incomprehensible. In order for these gruesome events to be conceived as a category of the real, journalists and citizens alike needed them to be filtered into a symbolic order. History as experience is arguably not possible without history as representation. Thus, one can argue that, paradoxically, it is exactly the narrative format of televison news as an es- tablished informational genre - rather than the footage by itself - that connotes reality, and in the case of 9-11 helped us affirm the realness of the attacks. This is something that Corner actually implies, stressing the importance of acknowledging the viewer's awareness of 'television as style' (Corner, 1996: 30 ) in audience research, interacting with a more direct perception. Different genres, program formats and aesthetics evidently engage the viewer in different ways of meaning-making.

Even if the television news format, through its conventionally established credibility, can be ascribed the power to connect people with reality, the 9-11 events do not seem to have been real enough on television. Many have made the case that 9-11 was a strong come-back for still images as a means to connect with reality (Zelizer, 2002). Where there were no words, seemingly, there was an abundance of photographs, and the demand for these documentary images is unprecedented. Again, in my view John Corner somewhat to hastily dismisses the powerful function of photographs when he pits television's 'visual immediacy' against still photog-

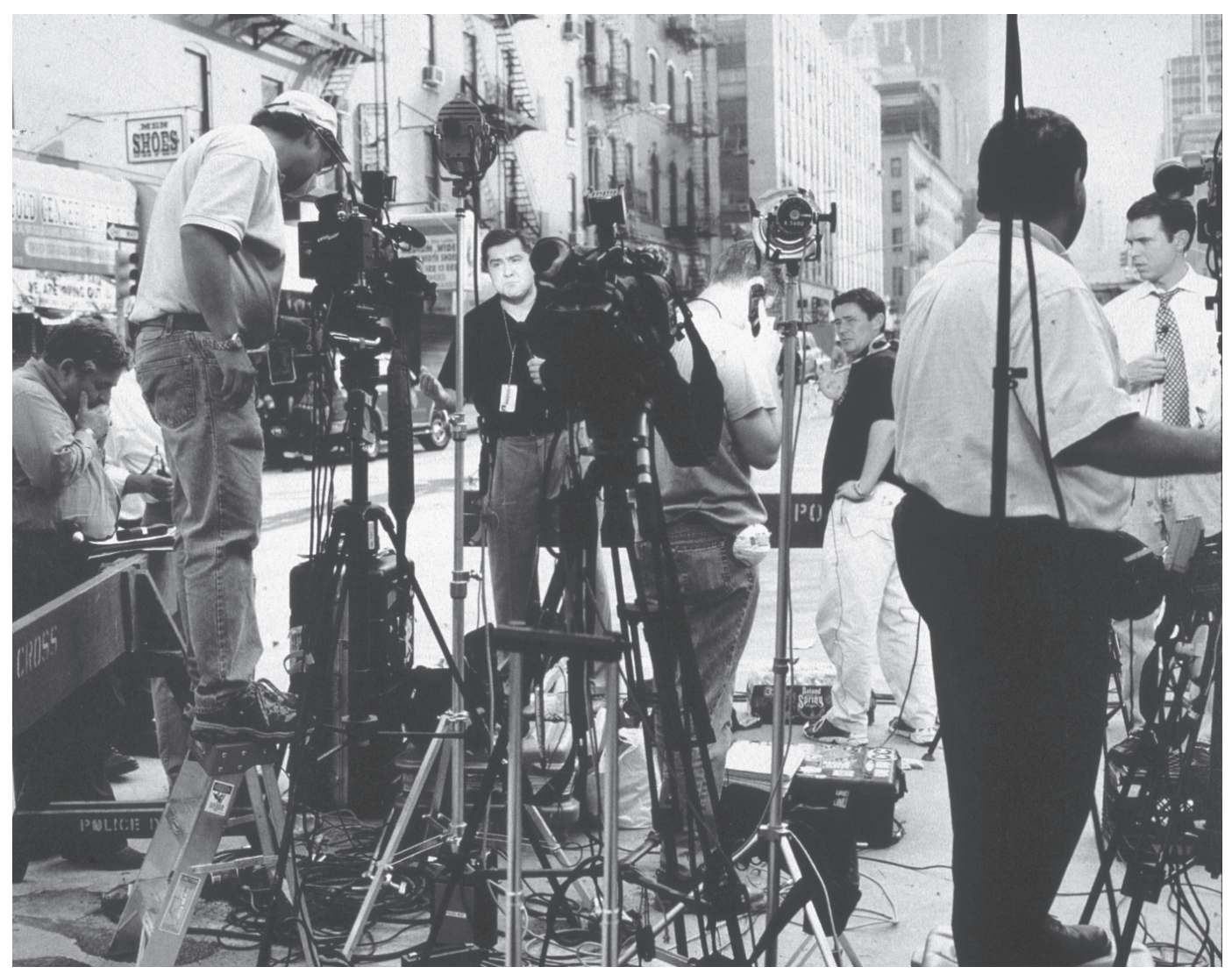

The media gather at the site of the disaster in the wake of the terrorist attacks, from here is new york. 


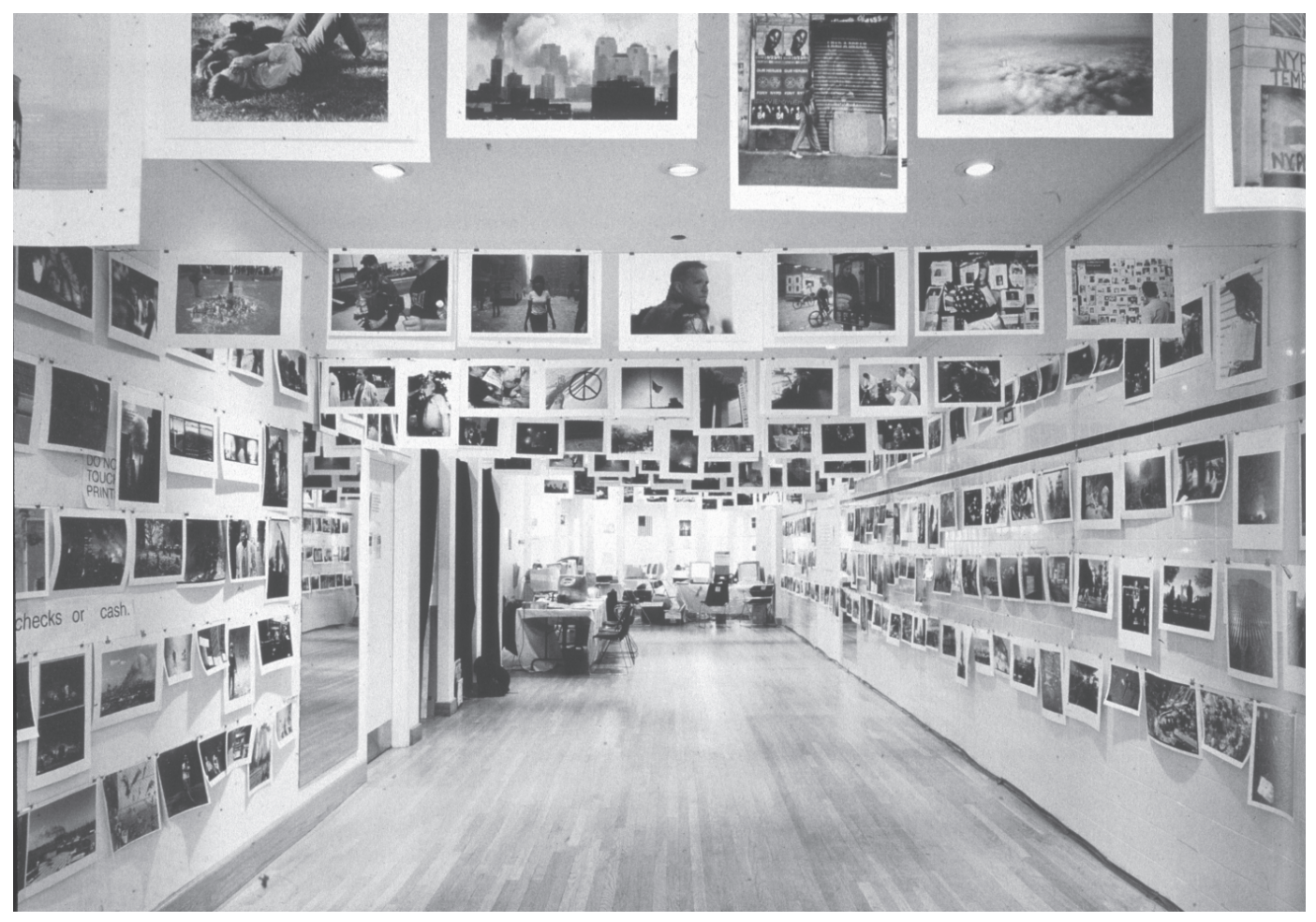

The photo show here is new york on Prince Street in Soho, New York City.

raphy as a more indirect medium: 'Even the most 'graphic' piece of print journalism cannot help but retain a distance between the events described and the reader's experience of them' (Corner, 1996: 30). This is to overlook the notion of the photograph as a trace, or index, which makes up a material, physical and thus extremely potent connection between image and referent. Furthermore, the still camera has the advantage of turning cultural and natural occurrences into graspable objects, material things. As the sociologist John Urry notes, it allows us to almost literally close the gap between representation and reality: 'To photograph is in some way to appropriate the object being photographed' (Urry, 2002: 127).

\section{'Here Is New York'}

With the events of September 11, photographs took center stage in the American culture (Zelizer, 2002). Not only were they frequently (re)circulated in news papers, news magazines, and eventually yearend reviews and comemorative volumes. Several of the most prestigious galleries and museums in New York City organized well-attended exhibitions with photojournalistic images from 9-11, among them
The New York Historical Society, the International Center of Photography and the Museum of Modern Art. The fact that influential cultural institutions today define news images as cultural artifacts worthy of high modes of display and contemplation can be seen as an acknowledgement - and a reinforcement of the increasing centrality that such images hold in our constructions of knowledge, history and memory. However, in addition to these official channels for the (re)circulation of photo journalistic images in the wake of 9-11, perhaps the most significant exhibition dedicated to this event is 'Here Is New York: A Democracy of Photographs'. This popular grass-roots photo show opened September 28, 2001 in an empty storefront on Prince Street in Soho. A year later it seems to have been established as a semi-permanent exhibition, touring around the U.S. and Europe, and a collection of the photographs has also been published in the best-selling book 'Here Is New York'. The main purpose of the project is to collect, display and preserve for historical purposes as broad and varied a view as possible of this event and its aftermath.

The subtitle, 'A Democracy of Photographs', captures the basic concept of the whole project: to provide an undiscriminating venue for everyone to 


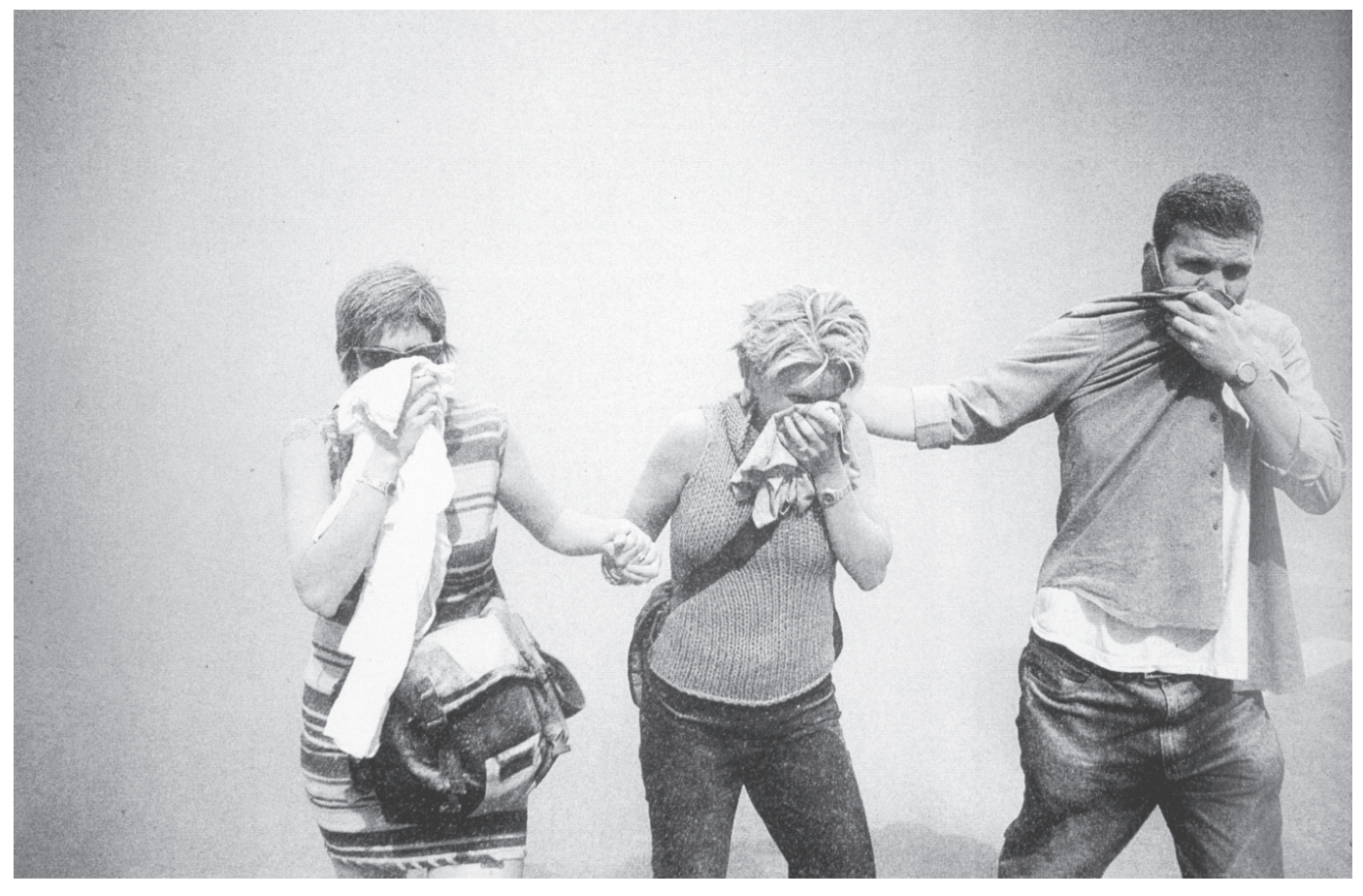

People fleeing after the collapse of the twin towers. Photograph taken by the world famous photographer Gilles Peress, from here is new york.

bear photographic witness to what happened. The images on display have been submitted not only by world famous photo journalists but also by amateurs of every age and background. Each photograph is digitally scanned, printed on archival paper, and casually clipped to wires strung along the walls or across the room in the makeshift gallery spaces. All photographs are displayed in what the organizers describe as a 'truly democratic style' anonymously, without labels or captions, and without frames. All of the prints are for sale to the public at the same fixed and nominal price of $\$ 25$ a piece. Net proceeds from the exhibition are donated to the Children's Aid Society for its World Trade Center relief efforts.

'Here Is New York' testifies to the taking and viewing of photographs as a common human response to the events of September 11. By May 2002 , the organizers estimated that the collection contained about 7000 photographs, that 750000 people had visited the gallery spaces, and that 600 000 prints had been made and sold. The continuously upgraded web site, www.hereisnewyork.com, had by that time had around 260 million hits from all over the world. The site, which allows for online sales of prints, has had an average of 1,5 million hits per day.
The organizers themselves explicitly dissociate their project from the hierachical, one-iconic-picture ideal of the mainstream press. Michael Schulan, a writer and owner of the SoHo gallery space states: 'September 11 has no single photograph to help people remember. No soldiers raising the flag at Iwo Jima. No soldier kissing a girl at Times Square. No firefighter holding a baby at Oklahoma city'. In contrast to traditional photojournalism - the edited, out-of-context, usually sensationalist presentation of one dramatic picture - the goal of this exhibition is to represent a collective, people's view of the historical events of 9-11. The concept of 'unframing' is also essential to the project. Charles Traub, one of the main organizers, stresses that the guiding principle has been to allow the photographs 'to speak for themselves [...] unframed either by glass, metal or wood, or by preconception or editorial comment'. Part gallery, and part memorial and public mourning space, the on-location show has brought people of all classes, ages, and nationalities together. Mr. Traub describes it as a 'physical web site', a kind of real Internet were all kinds of people can come together in a material space and contemplate (the images of) the historical event of the attacks. Clearly, the strong emphasis on locality and the local is a decisive factor behind the sucess: the gallery consti- 
tutes a locally situated global meeting place, an intimate room that invites visitors to take personal measurement of the public event. This is further stressed by the strong local focus of the photos: the streets, buildings and people of New York City during and after the attacks emerge as an almost palpable presence in these images.

The exhibition has obviously answered to, and encouraged a widespread desire for community in the wake of the 9-11 attacks. In contrast to much of the top-down, one-way or 'para-social' communication of traditional news media, it allows for popular social interaction and participation, offering a sense of place, sharing, and belonging. The show's lack of hierarchy not only makes the experience of viewing the images less formal and exclusive, it also erases the traditional borders between the artist-photo journalist and the beholder. Here everyone is a potential contributor, any visitor can identify his or her own photograph in the collection.

However, what makes 'Here Is New York' popular is also what opens it to critique. Ultimately, the project seems to be founded on the idea that somehow, by the massing and 'unframing' of these photographs, history as such will emerge in a direct and self-evident presence. This notion of naive historical realism is exactly what propagandists and myth-makers make their living on: the more unnarrated and non-explicit the ideological message of an image, the more quiet and effective its impact. Consequently, I would argue that the more specific information we get about when, where, by whom and how a photograph was created, the stronger its power as a historical statement, and the lower the risk of it being misused for disparate and possibly manipulative purposes.

In contrast to what Charles Traub states, that the show has 'raised consciousness on a world level in a non-political, non-ideological way', a good case can be made for the highly ideological character of 'Here Is New York'. As the title makes clear, in its original version the show has been constituted by, and feeds a national and cultural ethnocentrism. With its myopic focus on New York City, on 'us' as opposed to 'them' (non-Americans, non-Westerners), the rest of the globe has to a large degree been excluded from concerns. In an overall perspective, the project's collection of photographs echoes much of the official self-glorifying rhetoric of the U.S. in the wake of the attack. Americans are almost exclusively depicted in the roles of self-sacrificing (male) hero - policemen and firefighters - or innocent (female) victim; as patriotic, peace-loving, good Christians still standing tall in the face of fa- natic, Muslim evil. Understandably, the main theme of the photographs is emotional reassurance and confidence-building. However, this therapeutic patriotism excludes a more nuanced political understanding of the disastrous events. That is, an acknowledgement of the U.S. as a nation among nations, the world's sole, self-satisfied superpower with a debatable record of geopolitical and economic alliances and actions.

By the late spring of 2002 the organizers started taking this short-sightedness into account, and are now encouraging contribution of images from the rest of the world. However, a closer look at the collection available on-line in August 2002 reveals that 4708 of 4779 photographs are from New York City. The category 'Afghanistan' contains only 22 images - less even than the category 'Rescue dogs', which contains 29 photos. Not surprisingly, the most requested photos - a sample of which is also presented on-line - are all from New York City. They are either of a romantic-heroic character (Lower Manhattan in sunset with the twin towers still intact or firefighters raising the American flag in

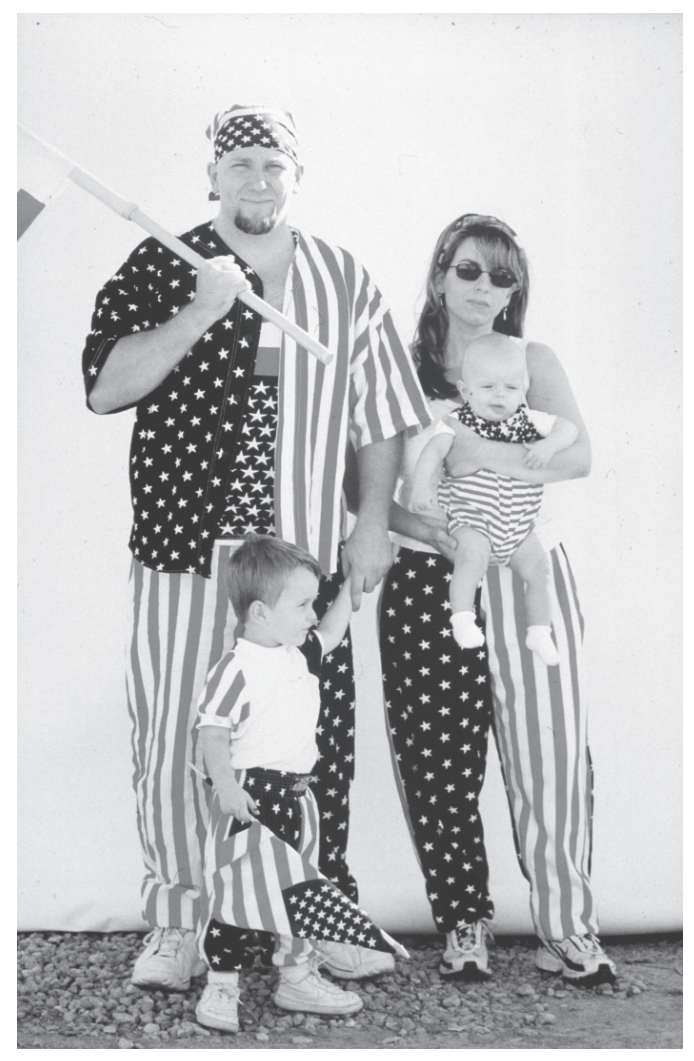

Photograph taken by amateur in the wake of September 11, from here is new york. 


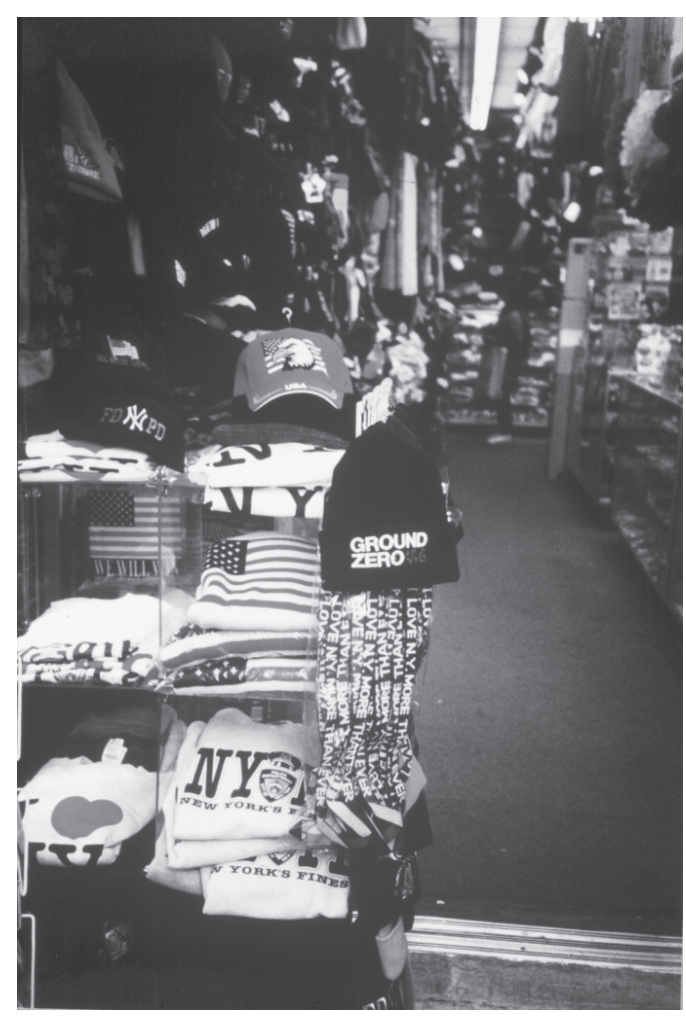

Street vendors around ground zero selling clothes... the rubble of the World Trade Center) or disaster pictures (terrified New Yorkers watching the twin towers in flames, the second plane about to hit the south tower). Considering the fact that these images are unprecedented bestsellers - according to Traub several of them are by now the most sold photographs in history - and that the collection as a whole is planned to be institutionalized as an official 9-11 visual archive and memorial, the political implications of this 'apolitical' project would need to be more explicitly acknowledged than the current 'hands-off' abdication.

If the popular success of 'Here Is New York' can to a large extent be explained by its local, participatory, community-engendering profile, there is another factor that needs to be ackowledged: the possibility to buy photographs at an affordable price. Whether you visit the show on-location or on-line, you can bring a materialized memory into your home. This is obviously a main attraction of the project, arguably related to the phenomenon of street vendours selling disaster pictures by the World Trade Center site itself.

\section{Disaster Tourism}

The unathorized hawking of goods by street vendors, conducting business with simple folding ta-

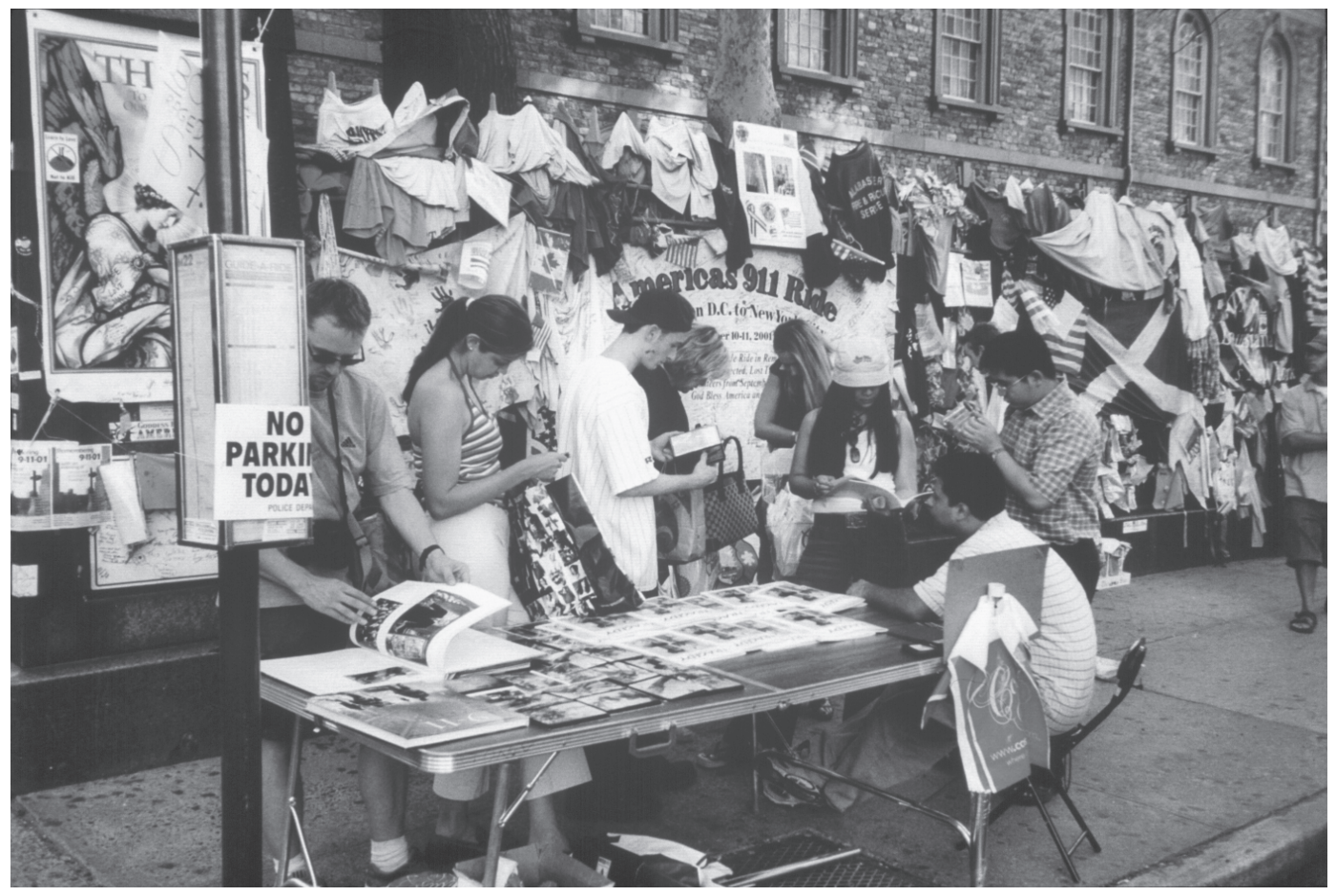

...and knockoff press photographs. 
bles around 'ground zero', has stirred considerable public debate in the U.S. The criticism has focused on the selling of baseball caps, knitted wool hats and T-shirts bearing F.D.N.Y. and N.Y.P.D. logos. It has been considered 'tasteless' and 'dishonorable' to exploit the New York police officers and firefighters, the proclaimed heroes of September 11 and workers in service of the public good, for private gain. In contrast, the selling of knockoff press photographs - some of them by star photographers such as Susan Meiselas and James Nachtwey - has not caused any public criticism. This is remarkable considering the obvious copyright violation. The news images are sold as postcards, as individual photographs (ready to fit into the family photo album), and printed or embroided on T-shirts. They are also presented in the form of seemingly "official" memorial photo books, and pocket format, 'personal' photo albums. The last item is particularly interesting: a mass fabricated, anonymous commodity evoking the authenticity of a private memory album. It offers the disaster site tourist a ready-made 'memory' of the terrorist attack, a souvenir - if not to say trophy - demonstrating that the owner has really been there, implicating her or him as a direct

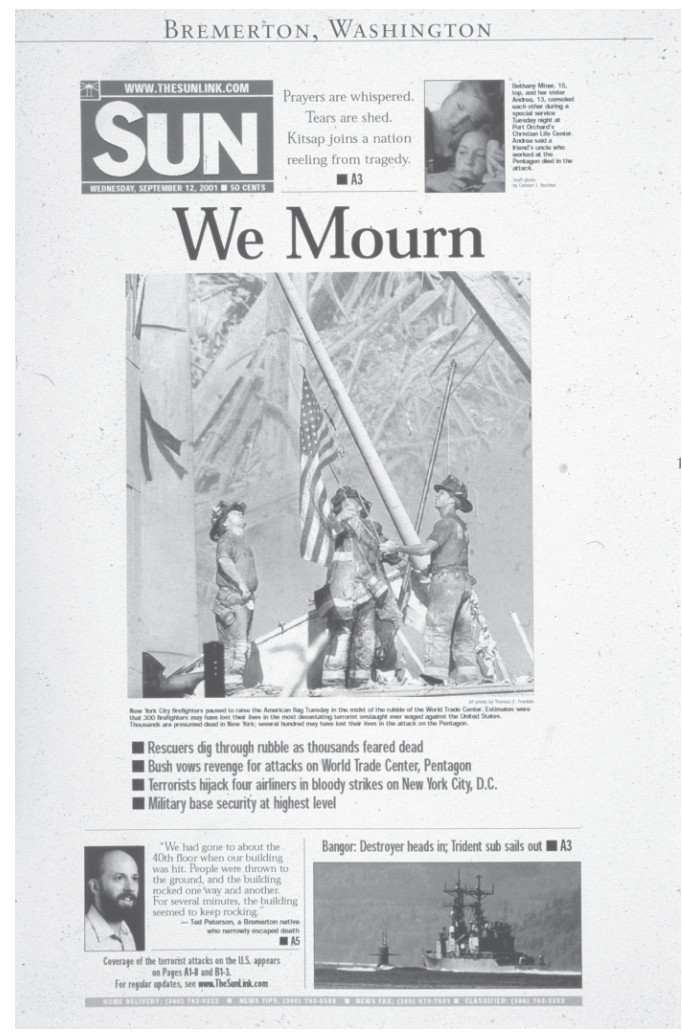

eye-witness to the world historical event. A public site is turned into a (quasi)private sight, the 'incomprehensible' catastrophy into a tangible, graspable object. Furthermore, the illicitly appropriated photographs in the album are also enscribed into a Hollywood narrative format, with masculine heorism and patriotism as its lead motif, which further assimilates the traumatic events into a normalized, easily consumable commodity.

Like with 'Here Is New York', the marketing strategy of the street vendors is to convert the public into the personal, the strange into the familiar, distance into intimate presence. They 're-territorialise' (Morley and Robins, 1995: 18) the global news event, perform a local (re)appropriation of it, reconnect it with the particularities of place and context. The physical nearness of the street vendors to the World Trade Center, the actual site of the disaster, is decisive in this respect. As James E. Young observes in his analysis of the Holocaust memorial camps at Majdanek and Auschwitz, 'The magic of ruins persists, a near mystical fascination with sites seemingly charged with the aura of past events, as if the molecules of the sites still vibrated with the memory of their history' (Young, 1993: 119). In
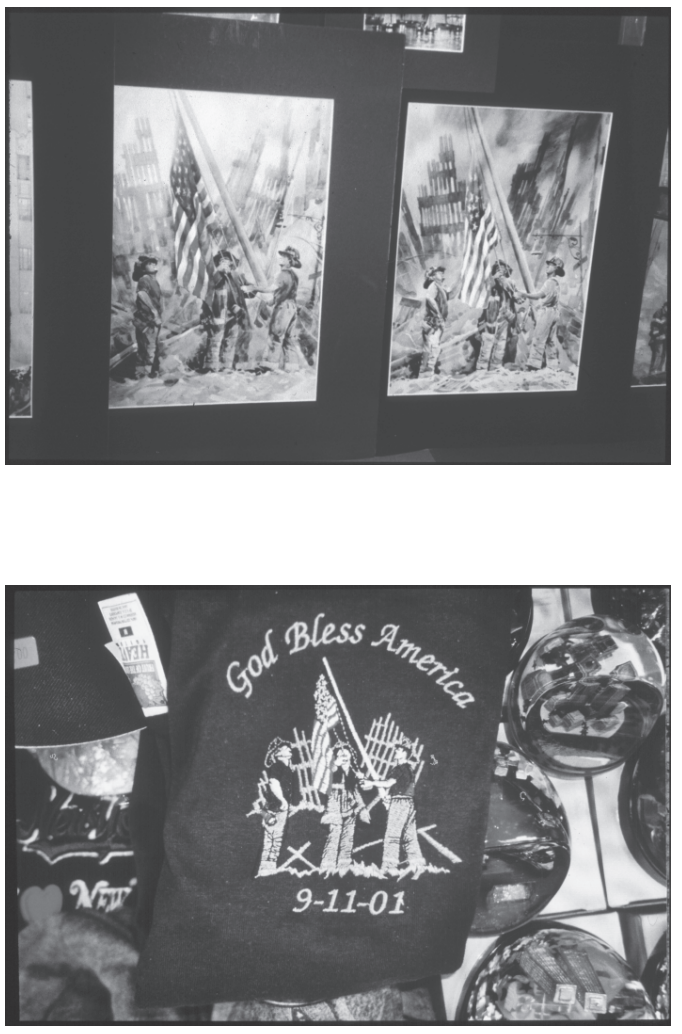

Thomas E. Franklin's photograph has become an unrivalled icon of 9-11. 
other words, the spirit of the place serves to bridge the distance in time from the historical event and lend authenticity to the street vendors' enterprise.

Hand in hand with this fetishization of the physical remnants of history, of the materiality of the historical place, goes the wide-spread promotion of Thomas E. Franklin's press photo to become an unrivalled icon of 9-11. The street vendors recirculate it not only in books and albums, but in the form of postcards, framed and glazed pieces of photographic 'art', as T-shirts, drawings and paintings. What the image depicts, three firefighters triumphantly rasing the Stars and Stripes amidst the ruins of the World Trade Center, is exactly a reclaiming of the local territory attacked by outsider, global terrorists. The photo places us at the very scene of the crime, the still smoking ashes of ground zero, a mythical notion of place analogous to what Germans call Stunde Null, or the Zero Hour. It is the point of absolute defeat and destruction, but also the beginning of time, a pure moment - and, in this case site - of origin, where the traumatic past can be eradicated once and for all, the end and beginning of history. Franklin's picture glorifies the victorious resurrection of the American nation, born again, innocent but hard. The flag-raising by men in uniform gives notice to the world that Americans stand united and eternally ready to ensure their hegemony - by force of arms, if necessary. The explicit iconographic reference to Joe Rosenthal's photograph of American soldiers raising the flag on Iwo Jima is not without ideological implications. Franklin's picture activates the political agenda of this touchstone for American culture: the cold war doctrine of armed deterrence, interventionism with global reach capabilities, and expanded military power.

Like 'Here Is New York', the street vendors display and sell documentary photographs of 9-11 in a popular, informal setting. However, the differences between the two enterprises are more conspicuous than the similarities. 'Here Is New York' enjoys the prestige and legitimize stature of a cultural (if not art) institution. Located in a serene gallery space, the show invites viewers into serious contemplation of the images. Since the profit goes to charity, one can buy a 9-11 photograph with the blessing of serving a good cause, rather than the curse of voyeuristic exploitation. The participatory, grassroots concept also grants the project a stamp of authenticity. In contrast, the street vendors, located on the sidewalks of New York City's commercial district, are disqualified from any cultural legitimacy. Theirs is an enterprise associated with com- mercialism, tourism, inauthentic souvenirs, cheap entertainment, spectacle and raw American capitalism. Yet, can we really say that there is an absolute, or at least significant, difference between the meaning and function of a photograph in the gallery and in the street? Do people buy the images for different reasons in the two different contexts; do they interpret and use them differently? Obviously, much more work needs to be done considering the meaning, reception and practical use of disaster images. This is a task that now leads me to make a case for the field of visual studies.

\section{The Politics of Viewing and Valuing}

Although the interdisciplinary project of visual culture has been around for more than a decade now, and in spite of the rapidly growing number of academic courses, publications and conferences on the subject, the field is still fluid and subject to controversy. Visual culture emerged, according to one view, as a response to the media convergence and global flows of images in the late 20th century (Cartwright, 2002), centered on understanding how images function in a broader cultural sphere and on how people use visual media to make meaning in everyday life.

While one could have hoped for a broad range of visual scholars to take on the challenge of this open venture and help promote and specify it productively, much of the discussion has unfortunately been clouded by the defensive criticisms from the field of art history. In 1996, October published the now infamous 'Visual Culture Questionnaire', which more or less set the terms for subsequent debates on the subject. The respondents - mainly art historians - were focused more on airing anxieties about the dissolution of traditional art history than on seriously exploring what a visual culture approach could bring to the analysis of how images and their viewers make meaning in an era of cultural globalization. Apparently they were provoked by the growing preference for an 'anthropological' or 'relativist' model of cultural analysis in the emerging field of visual studies. Thomas Crow, for example, dismisses it as a 'a misguidedly populist impulse' (Crow, 1996: 34), a complaint echoed by Martin Jay who speaks of 'a pseudopopulist leveling of all cultural values' (Jay, 1996: 44).

To refute this critique is like engaging in shadow-boxing, since so little of it is moored in actual work in visual and cultural studies. As Douglas Crimp's incisive critique of this debate makes clear, we are left with a 'projection' in which 'a social and 
historical de-contextualization of visual culture takes place that is quite the opposite of what much work in cultural studies strives to achieve' (Crimp, 1999:153). Crimp not only presents a substantial defense of visual studies, refuting the October issue's critique by citing factual research in the field, but also concretely demonstrates the significance of a visual cultural approach to contemporary art. By invoking the important, but in many accounts missing, link between Andy Warhol's work and the queer counter-cultural milieu that inspired his early filmmaking, Crimp alters our view of both Warhol's art and the history of gay identity politics.

In the recently released Journal of visual culture, Martin Jay is asked to reflect upon his cautions in the 1996 questionaire against visual culture's 'democratic impulse', that is, its readiness to include, in his words, 'all manifestations of optical experience, all variants of visual practice' (Jay, 1996: 42). Interestingly, six years later he qualifies his previous statement, recognizing the fundamental advances of visual studies. Jay states: 'By democratization, I simply meant the growing willingness to take seriously as objects of scholarly inquiry all manifestations of our visual environment and experience, not only those that were deliberately created for aesthetic effects' (Jay, 2002: 88).

It is hard to think of a stronger overall case made for visual culture than this acknowledgement of traditional disciplines' inclination to exclude vital areas of visual culture that are more than worthy of serious academic study. The field of photojournalism is but one example of this scholarly oblivion. If Martin Jay thus may seem to have reconsidered his earlier dismissal of this approach, what the one hand gives the other curiously takes back. After eloquently presenting a case for the inclusiveness of visual studies, he turns around and reiterates the complaints from the October questionnaire. To overcome 'the danger in such an indiscriminate levelling', he finds it necessary to 'maintain the vexed distinction between genuine works of art and derivative kitsch, high and low, avant-garde and academic art, at least as a way to avoid the promiscuous reduction of everything to the same level of cultural significance' (Jay, 2002:88). Jay leaves it at that, without presenting any argument as to why, for whom, and to what purposes fixed notions of quality and excellence are so important to maintain - notions, which he himself implies in the excerpt previously quoted, that are deeply ideological, undemocratic, and elitist. As others have argued before me (Rogoff, 1998: 20), visual studies' rejection of antiquated value hierarchies does not mean that it advocates an undifferentiated relativism in which everything is equal to everything else. Rather than differentiating between the supposed value inherent in objects and images, proponents of visual culture analyze and make distinctions between different viewing practices and processes of cultural assessment in particular historical situations.

\section{Aesthetics and Politics}

To a certain extent, the defensive positions that Jay (and others) take towards this emerging arena of inquiry is explicitly rooted in a fear that it rules out considerations of the aesthetic in and of itself. In their view, the aesthetic specificities of images, especially those that have been deliberately worked out in terms of an aesthetic ideal, cannot be made justice to within the culturalist paradigm.

However, if Jay thus manifests a distaste for the politicization of the aesthetic, a fear of the reduction of aesthetic works to political realities, I suspect that an even stronger fear can be distinguished in his and others' resistance to visual culture: that of the aestethicization of politics - that is, of the absorption of all political realities into images and 'simulacra'. The loss of the idea of referential reality is a fundamental aspect of our postmodern predicament. In the society of the image - of simulation, screen, network, spectacle - the hyperreal threatens to overtake the real. Baudrillard says about contemporary images: 'if they fascinate us so much it is not because they are sites of the production of meaning and representation - this would not be new - it is on the contrary because they are sites of disappearance of meaning and representation' (Baudrillard, 1985: 133).

As long as we confine our methods and objects of study to traditional art history, there is not much at stake in Baudrillard's theory of a psychotic collapse of representation and reality. Such an approach entails applying our interpreting skills to contemplate the aesthetic specificities of artistic images - often produced as self- or medium-reflexive within the narrow, de-politicized context of a reified art history. Baudrillard's claim becomes more of an issue if we open up the study of artworks to the more expansive, politically motivated inquiry of visual culture; the project of contextualizing artworks in terms of broader social practices almost inevitably evokes the complex question of how representation relates to reality, aesthetics to politics.

However, when we apply Baudrillard's argument to a radically different category of images, a 
category usually expelled from the art historian's list of objects worthy of aesthetic consideration, it really comes to a head. I am, of course, referring to documentary news photography: images that are not only subjective expressions but also, in a technical sense, objective imprints of the physical world. They are proof of wars, famines and natural disasters around the globe, proof of indisputably real people and real suffering. Can we really buy into the argument that these types of images are 'sites of disappearance of meaning and representation', detached signifiers that overtake and do away with the referential reality that in some sense generated them? If these images ultimately refer only to themselves, and there is no outside to them, 'no retreat' (Baudrillard 1985: 133), how do we account for the blood and tears shed by the people portrayed? How do we account for the social and political injustices that these images set out to not only document but also, in the spirit of journalism's Enlightenment ideals, counteract?

I suspect that it is exactly this nightmarish scenario of the disappearance of reality into a limitless interplay of self-mirroring images that deters some scholars from the idea of subjecting documentary photographs to aesthetic analysis. If we are to take Martin Jay at his word, and also consider news images as 'complex figural artifacts' worthy of examination on their own terms, we obviously run the risk of reducing political realities to aesthetic devices. If we analyze them in terms of iconography, rhetoric and symbolism, will there be anything left but style? Furthermore, is it at all defensible ethically to talk about style when we are dealing with images that, after all, document the tormented and dead bodies of others? In particular, deeply traumatic events like the September 11 attacks, events so extreme that they seem unclassifiable, would by many be held to defy the very possibility of historical, let alone aesthetic, representation.

\section{Representation of/as Trauma}

The big existential crisis of our time, and a core issue in the contemporary epistemological debate on how to establish historical knowledge, historical 'truth', stems from the difficulty to gain footing in an irreducible reality that exists before or beyond discourse. However, this fact does not necessarily imply that referential reality is purely absent or completely coded, that it is but an effect of representation. Rather, as the case of documentary news images clearly shows, we need a concept of reality that goes beyond mere conventionalism, and a model of representation that goes beyond binary oppositions between the image as referential or as simulacral. Not either-or, not Baudrillard's apocalyptic collapsing of one category into another, but both at once.

In this regard, Hal Foster's nuanced notion of 'traumatic realism' is arguably more productive (Foster, 1996: 130). In his analysis of Andy Warhol's repetitions, Foster points to a 'third way' of reading images as both 'connected and disconnected' (1996: 130). They screen and protect us from the traumatic real, at the same time as they point to the real and allow it to poke through the screen of repetition. This concept of traumatic realism is extremely useful as a key to understanding the frantic (re)circulation of documentary photographs in the wake of September 11. The widespread creation, viewing and collecting of these images can be read exactly as a way of dis/connecting with a traumatic real: as 'a warding away of traumatic significance and an opening out to it, a defending against traumatic effect and a producing of it' (Foster, 1996: 132).

The complex issue of if, how, and when to represent historical trauma inevitably evokes references to the Holocust - the ultimate event of suffering. The commonplace assumption is that this event 'Auschwitz', 'the Final Solution' - is the extreme limit case that threatens our traditional conceptual and representational categories. The obligation to bear witness to and document this traumatic past is undercut by the notion that the record should not be distorted or trivialized by inadequate representation. Usually the aesthetic is the first category to be targeted in this debate about proper Holocaust representation: Theodor Adorno's 'to write poetry after Auschwitz is barbaric' is notorious (Adorno 1949/1981:34). For Adorno, all forms of artistic expression seemed irrelevant or even criminal in the face of torture and death. Moreover, beside the apologetic temptation of artistic renderings, they also effect pleasure, which for Adorno seemed antithetical to the historical event of the Holocaust. However, it is rarely acknowledged that Adorno returned to 'Auschwitz' again and again, revising his original stance by holding up the unique potential of art to give an authentic voice to suffering (DeKoven Ezrahi, 1992: 260, Weissberg, 2001: 14).

Moreover, Andreas Huyssen points to a way to go beyond the stalemate in debates about how to represent the Holocaust 'properly' or how to avoid aestheticizing it by emphazing another of Adorno's key concept: mimesis (Huyssen 2001). Huyssen reads Adorno against the lingering effects of the high 
culture versus mass culture dichotomy that, ironically, were first and most influentially articulated by Adorno himself. Looking at Holocaust representations in terms of their mimetic dimensions, allowing for all kinds of narrative and figurative strategies in a variety of media and genres, is, as Huyssen demonstrates, more productive than trying to construct a Holocaust canon based on narrow aesthetic categories that pit the unrepresentable against aestheticization, art against mass culture.

This line of argument undermines Martin Jay's position, which still rests on the unquestioned modernist dichotomy that pits mass culture against forms of high art, aesthetic quality against political relevance. He, like many other critics of visual culture, seem to pre-suppose a bipolar positioning of the aesthetic and the political, where the one category threatens to collapse into the other if they are not programmatically separated. In contrast, I want to stress the possibility of a skillful examination of the aesthetic, not only in itself but also of how the aesthetic functions within and feeds a particular politics or ideology. We cannot fully understand the power and popular resonance of documentary news images if we do not account for their aesthetic and rhetorical qualities. Such an analysis does not imply a fetishistic denial of the documentary image's referential relation to reality, on the contrary, it promotes a richer understanding of its political and historical contingency.

\section{Conclusion}

The notion of a pictorial turn, of a culture totally dominated by pictures, of an age of 'spectacle' and 'surveillance', seems, uncannily, to have materialized in the iconomania accompanying the September 11 terrorist attack and its aftermath. This is by far the most photographed event in history, and the popular demand for documentary images - in particular still photographs - representing it seems to have reached a point few could have anticipated. How, then, are we to understand the social and psychological role of documentary photography in connection with 9-11? On the one hand, critics talk of voyeurism and pornography of violence. The pictures of people jumping from the twin towers, to pick the most extreme example, obviously run the risk of invading the privacy not only of these helpless human beings, but also of the viewer being forced to witness their fatal descent. The moral and political implications of the exposure - not to say exploitation - of the 'distant suffering of others' (Boltanski, 1999) has received increasing attention in media studies, disqualifying the simplistic journalistic argument that shocking images serve to raise public consciousness and counteract violations of human rights. So far, there is no evidence that images of atrocity, no matter how graphic, stops atrocity from reocurring (Moeller, 1999; Perlmutter, 1998; Zelizer, 1998).

On the other hand, many who have seen or helped organize the exhibition 'Here Is New York' have made the case that the photographic images have helped people respond to and make sense of what happened on September 11. The taking as well as viewing of photographs is believed to have helped the public bear witness and promote its own healing. By reclaiming the haunting disaster images from the media flow and offering the public a consecrated space to contemplate them in the presence of fellow human beings, 'Here Is New York' seems to have enabled a unique sense of communitas and working through of the 9-11 event. However, the pictures sold by the street vendors could very well play a similar therapeutic role for people viewing and buying them. This ultimately points to a blank spot in the field of media studies: We still know very little about the precise ways in which people view documentary photographs, whether in the streets, in the paper or in gallery spaces. What precisely does the sight of these photographs awaken in viewers? Historical knowledge? A sense of evidence? Fear, grief, excitement, relief? Why do people buy disaster pictures? To remember or, rather, to forget? What do they actually do with the pictures - put them away in a drawer, include them in their private photo albums, hang them on the wall? Is there any significant difference between the experience of viewing culturally 'legitimized' photographs (in the news media, official commemorative books, museums and galleries) and the appropriated, commodified images sold in the streets?

There is also reason to caution against the tendency among some television scholars to pit the 'abstract' and 'distancing' medium of still photography against the 'visual immediacy' of television. The case of 9-11 can be used to complicate this argument, since it indicates that the postmodern, immediate medium of television to some degree failed to connect the audience with reality. To a remarkable extent, people turned to the older, pre-television medium of still photography in order to defictionalize the unfathomable terrorist deeds. It is worth citing the Village Voice critic Vince Aletti: 'I overdosed on TV coverage long ago, but I keep looking for a picture that will make it all real, help me understand, jolt me, make me feel something be- 


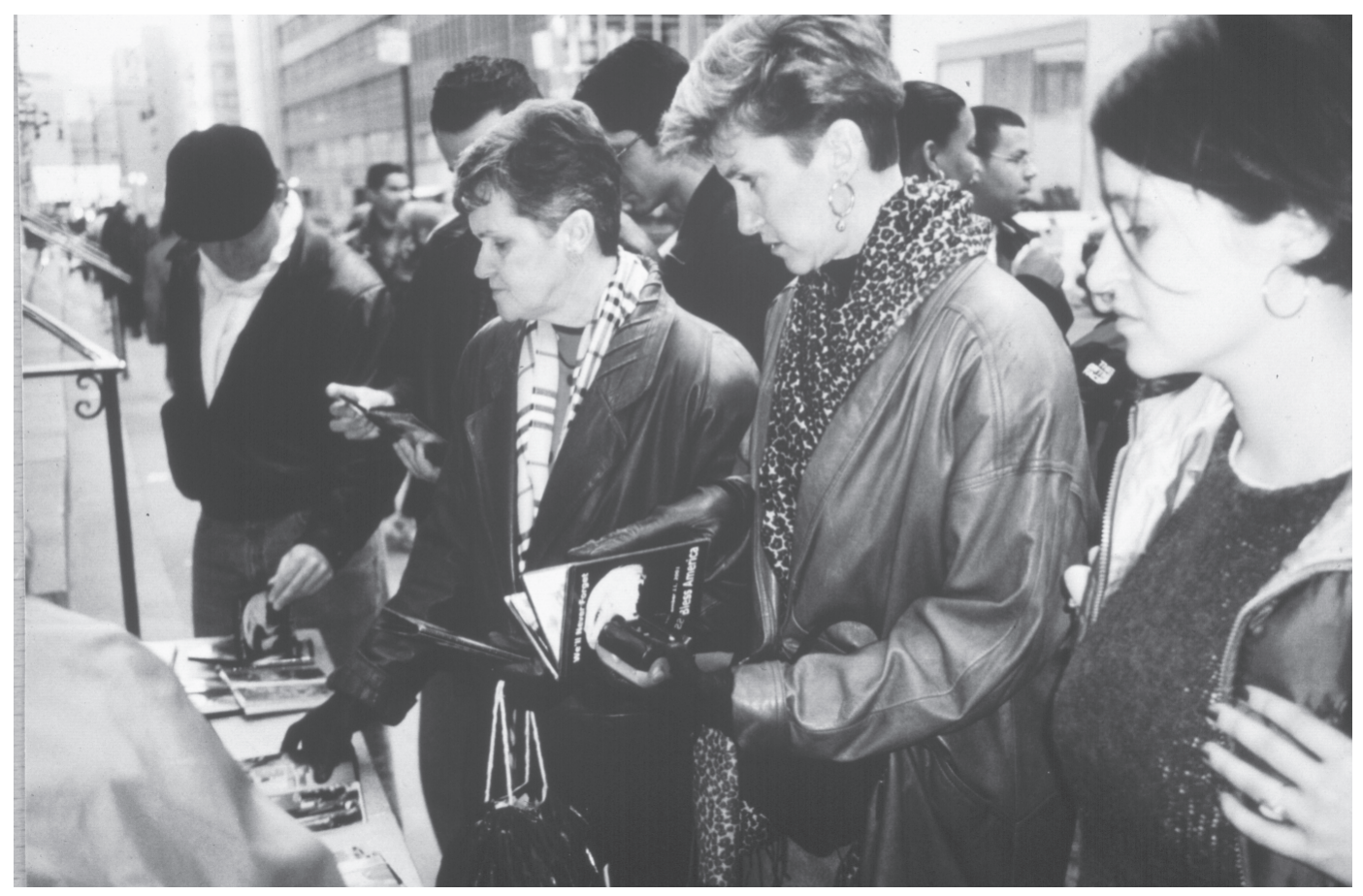

People bying photographs at gorund zero. To walk away with an image related to 9-11 is to walk away with a piece of the event, similar to when people carried off parts of the Berlin wall.

sides numb'. Arguably, it is the phenomenological qualities of photographs that make the difference. They are material things, objects that you can hold, scrutinize, share, keep, own, put away and take out again. Further, at work here is also the popular belief in the power of photography to magically resurrect reality. The photographs (re)circulated in the wake of 9-11 seem to take on the function of relics. They are perceived not (only) as representations of the real, but as actual pieces of the real. To walk away with an image related to 9-11 is to walk away with a piece of the event, as was the case when people carried off parts of the Berlin wall. There is, as W.J.T. Mitchell points out, a prevailing superstitious attitude towards images and objects in our culture. Practices like totemism, fetishism, idolatry, and animism are far from eradicated. Mitchell says: 'We are stuck with our magical, premodern attitudes toward objects, especially pictures, and our task is not to overcome these attitudes but to understand them'. For all the rhetoric about the power of news images to change the world, shock the public and set the agenda for governmental policy, we still do not know much about how they operate on viewers and on the world (redundant?). A lot more work is needed on how they communicate as signs and symbols, and what sort of power they have to af- fect human emotions and behaviour. Considering the increasingly important role news images play in the formation and documentation of historical events, and how deeply enmeshed they are in our political, social and cultural everyday life, there is an obvious need for an overall, interdisciplinary approach like visual culture. With its dismantling of antiquated value hierachies, it has paved the way for an academic legitimization of the study of journalistic images, and of how they function not only within the context of news journalism, but in culture at large. The strength of visual culture is that it emphasizes both the importance of studying the social field of the visual, the everyday practices of looking, and of the reconsideration of non-art images - like news photography - as complex artifacts worthy of examination in their own right. As I have argued in this article, the strong resistance to the visual culture approach from several prominent scholars in the field of visual studies can be ascribed to a deeprooted fear of conflating aesthetics with politics which, after all, was the ultimate strategy of fascism. However, the political and psychological impact of documentary photographs cannot be fully explored unless their aesthetic qualities are taken into consideration. We cannot understand the power and popular resonance of Franklin's photo of 
the three firefighters, for example, if we don't take account of its aesthetic devices - and the way these devices feed the official self-glorifying rhetoric of the U.S. in the wake of the attack. Reading the 9-11 photographs as cultural artifacts with rhetorical qualities endows us with a richer understanding of how they make us percieve this historical event in different ways. It is precisely as representations, not presentations, that documentary photographs help us connect with the real and integrate traumatic historical events like 9-11 into a symbolic,

\section{Note}

1. Andrew Heyward, President CBS News, stated at the seminar 'Television and the War on Terrorism' at The Museum of Television \& Radio, NYC, Monday February 11, 2002.

\section{References}

Adorno, T. W. (1949/1981) 'Cultural Criticism and Society', tr. Samuel and Shierry Weber, Prisms, Cambridge, Mass.: MIT Press.

Baudrillard, J. (1985) 'The Ecstasy of Communication', in H. Foster (ed.) Postmodern Culture, London: Pluto.

Baudrillard, J. (1988) The Evil Demon of Images, tr. Paul Patton and Paul Foss, Sydney: University of Sydney.

Baudrillard, J. (2002) 'L'Esprit du terrorisme' in Harper's Magazine, February 2002.

Boltanski, L. (1999) Distant Suffering: Morality, Media and Politics. Cambridge: Cambridge University Press.

Cartwright, L. (2002) 'Film and the Digital in Visual Studies: Film Studies in the Era of Convergence', in Journal of Visual Culture, Vol 1(1):7-23.

Corner, J. (1995) Television Form and Public Adress. London: Edward Arnold.

Crimp, D. (1999) 'Getting the Warhol We Deserve. Cultural Studies and Queer Culture', in Visual Arts and Culture, Vol 1(2): 149-67.

Dayan, D. and E. Katz (1992) Media Events. The Live Broadcasting of History. Cambridge, MA: Harvard University Press.

DeKoven Ezrahi, S. (1992) 'The Grave in the Air: Unbound Metaphors in Post-Holocaust Poetry', in Friedlander, S. (ed) Probing the Limits of Representation. Nazism and the 'Final Solution'. Cambridge, MA: Harvard University Press.

Ellis, J. (2000) Seeing Things. Television in the Age of Uncertainty. London: I.B. Tauris. that is comprehensible, order. However, as Hal Foster's notion of traumatic realism makes clear, their power to do so is nevertheless given by their paradoxical ability to let the real 'shine through' the screen of representation. Quite contrary to Baudrillard's iconoclastic thesis, I believe that the most amazing thing with these documentary photographs, and the challenge for any scholar interested in understanding their power, is that, coded and conventional as they are, they can still be so real to us that we even kill and die for them.

Foster, H. (1996) The Return of the Real. Cambridge, MA: MIT Press.

Freud, S. (1914/1958) 'Remembering, Repeating and Working-Through' in Strachey, J. (ed.) Standard Edition of the Complete Psychological Works, vol XII, London: Hogarth Press.

Freud, S. (1917/1963) 'Mourning and Melancholia', in P. Rieff (ed.) General Psychological Theory, New York: Collier Books.

Friedlander, S. (1992) Probing the Limits of Representation. Nazism and the 'Final Solution'. Cambridge, MA: Harvard University Press.

Hartman, G. (1992) 'The Book of the Destruction', in Friedlander, S. (ed.) Probing the Limits of Representation. Nazism and the 'Final Solution'. Cambridge, MA: Harvard University Press.

Huyssen, A. (2001) 'Of Mice and Mimesis: Reading Spiegelman with Adorno', pp. 28-42 in Zelizer, B. (ed.) Visual Culture and the Holocaust. New Jersey: Rutgers University Press.

Jay, M. (2002) 'That Visual Turn. The Advent of Visual Cultue', in Journal of Visual Culture, Vol 1 (1):8792.

Mitchell, W.J.T. (1996) 'What Do Pictures Really Want?', in October no. 77, Summer 1996, pp. 71-82.

Moeller, S. D. (1999) Compassion Fatigue. How the Media Sell Disease, Famine, War and Death. London: Routledge

Morley, D. and Robins, K. (1995) Spaces of Identity. Global Media, Electronic Landscapes and Cultural Boundaries, London: Routledge.

October no. 77, Summer 1996, 'Visual Culture Questionnaire,' pp. 25-70. Cambridge, MA: MIT Press.

Perlmutter, D. D. (1998) Photojournalism and Foreign Policy. Icons of Outrage in International Crisis. New York: Praeger

Rogoff, I. (1998) 'Studying Visual Culture' in Mirzoeff, N. (ed) The Visual Culture Reader. New York and London: Routledge.

Scannell, P. (2001) 'Editorial', Media, Culture \& Society 23(6): 699-705.

Urry, J. (2002) The Tourist Gaze. London: Sage. 
Weissberg, L. (2001) 'In Plain Sight', pp. 13-27 in Zelizer, B. (2001) Visual Culture and the Holocaust. New Jersey: Rutgers University Press.

Young, James E. (1993) The Texture of Memory. Holocaust Memorials and Meaning. New Haven: Yale University Press.

Zelizer, B. (1998) Remembering to Forget. Holocaust Memory through the Camera's Eye. Chicago: University of Chicago Press
Zelizer, B. (2001) Visual Culture and the Holocaust. New Jersey: Rutgers University Press.

Zelizer, B. (2002) 'Photography, Journalism, and Trauma', in Zelizer, B. and Allan, S. (eds.) Journalism After September 11. London: Routledge. 